\title{
EFEKTIVITAS PROBLEM BASED LEARNING DAN PROJECT BASED LEARNING DITINJAU DARI KETERAMPILAN BERPIKIR KRITIS SISWA SD
}

\author{
Retno Triningsih ${ }^{1}$, Mawardi ${ }^{2}$ \\ ${ }^{1,2}$ Prodi Pendidikan Guru Sekolah Dasar, Fakultas Keguruan dan Ilmu Pendidikan \\ Universitas Kristen Satya Wacana Salatiga, Indonesia
}

Korespondensi. E-mail: 292016117@student.uksw.edu

\begin{abstract}
Abstrak
Tujuan melakukan penelitian ini untuk membandingkan keefektifanmodel pembelajaran Problem Based LearningdanProject Based Learning ditinjau dari keterampilan berpikir kritis siswa SD. Penelitian ini menggunakanjenisQuasi Eksperimental dengan desain Post test-Only Control Group Design. Populasi pada penilitian adalah peserta didik kelas 5 SD yang ada di Gugus Diponegoro Salatiga sejumlah 164 siswa, sedangkan sampelnya adalah seluruh siswa kelas 5 yang ada di SDN Mangunsari 01, SDN Mangunsari 03, dan SDN Mangunsari 05 sejumlah 111 siswa. Hasil yang diperoleh dari penelitian ini berdasarkan pada Statistik deskriptif dimana rata-rata modelProblem Based Learning sebesar 92.46, sedangkan rata-rata pada modelProject Based Learning sebesar 85.15. Hasil keterampilan berpikir kritis pada model Problem Based Learning lebih tinggi daripada modelProject Based Learning diperkuat dengan uji $\mathrm{T}$ diperoleh hasil nilai Sig. (2-tailed) sebesar0,047 < 0,05, dengan demikian terdapat perbedaan bermakna antara kedua kelompok.
\end{abstract}

Kata Kunci: Problem Based Learning, Project Based Learning, berpikir kritis

\begin{abstract}
The purpose of conducting this research is to compare the effectiveness of the Problem Based Learning and Project Based Learning models in terms of the critical thinking skills of elementary students. This research uses Quasi Experimental type with Post Test-Only Control Group Design. The population in the study were elementary school grade 5 students in the DiponegoroSalatiga cluster of 164 students, while the sample was all grade 5 students in SDN Mangunsari 01, SDN Mangunsari 03, and SDN Mangunsari 05 totaling 111 students. The results obtained from this study are based on descriptive statistics where the average Problem Based Learning model is 92.46, while the average in the Project Based Learning model is 85.15. The results of critical thinking skills in the Problem Based Learning model are higher than the Project Based Learning model reinforced by the T test results obtained by the Sig. (2-tailed) of $0.047<0.05$, thus there were significant differences between the two groups.
\end{abstract}

Keywords: Problem Based Learning, Project Based Learning, critical thinking

Copyright @2020, JRPD, ISSN 2615 - 1723 (Print), ISSN 2615 - 1766 (Online) 


\section{Jurnal Riset Pendidikan Dasar, 03 (1), April 2020 (51-56)}

RetnoTriningsih, Mawardi

\section{PENDAHULUAN}

Dalam kehidupan sehari-hari kita selalu berdampingan dengan masalah Matematika. Matematika merupakan suatu ilmupengetahuan sebagai sarana berpikir dengan logik yang tersusun dengan sistematik, dengan begitu maka siswa SD sulit untuk memahami maupun mencerna pembelajaran matematika secara baik. Maka dalam pembelajaran Matematika para pendidik maupun guru untuk mengaitkan proses dalam pembelajaran dengan mengaitkan benda konkret maupun nyata yang dapat membuat siswa berpikir dengan logis maupun kritis.

Berpikir kritis dalam Matematika yang dikembangkan untuk siswa berfungsi sebagai pencapaian kecakapan hidup. Pembelajaran Matematika wajib diberikan maupun diajarkan kepada siswa supaya dapat berpikir secara logis, matematis, sistematis, kreatif, dan kritis serta mampu bekerja sama. Dari pernyataan tersebut dapat terlihat bahwa keterampilan berpikir kritis matematis sangat dibutuhkan dalam menjalani kelangsungan hidup.

Keterampilan berpikir kritis merupakan bagian dari kecakapan matematis yang merupakan bagian penting yang sangat dibutuhkan dalam kehidupan. Pada keterampilan berpikir kritis Matematika ada hal yang harus dipahami oleh siswa antara lain berupa pemahaman konsep dan bagaimana siswa memecahkan masalah dengan keterampilan berpikir kritis yang mereka punya tentu saja membuat seseorang terdorong untuk selalu mencari penyelesaian dari masalah yang mereka hadapi. Dengan demikian, masingmasing siswa harus mempunyai berbagai macam metode penyelesaian masalah melalui pendekatan proses pembelajaran yang tepat. Hal ini dimaksud supaya siswa tersebut mempunyai keterampilan berpikir kritis yang terpacu dari beberapa kajian teori. Salah satunya strategi pembelajaran yang sekarang perlu diterapkan untuk meningkatkan keterampilan berpikir kritis untuk pemecahan masalah maka dalam pembelajaran perlu diterapkan model Problem Based Learning dan Project Based Learning.

ModelProblem Based Learning adalah model pembelajaran yang berbasis masalah yang dapat meningkatkan kreativitas siswa. ModelProblem Based Learning mempunyai ciri-ciri yaitu menggunakan permasalahan yang nyata yang harus dipahami dan dipelajari siswa supaya dapat melatih dan menumbuhkan keterampilan berpikir kritis dalam memecahkan masalah. ModelProblem Based Learning bertujuan untuk meningkatkan sikap yang aktif, mengembangkan pemikiran aktif dan inovatif, melatih kemampuan berargumentasi, melatih kepekaan, melatih berpikir bebas-aktif dan bebas-logis, dan melatih kemampuan pengintegrasian masalah. Selain model Problem Based Learning juga terdapat model lain yang dapat mendorong maupun mendukung dalam pengembangan pada keterampilan berpikir kritis matematis, yaitu modelProject Based Learning.

Pada model Project Based Learning juga sering disebut dengan model berbasis proyek dimana guru akan menugaskan siswa untuk menciptakan suatu bentuk hasil belajar. Dalam pembelajaran ini siswa meningkatkan dan mencari sendiri yang dikerjakan secara kelompok maupun sendiri sehingga dapat merangsang peserta didik meningkatkan kemampuan yang mereka miliki. Melalui modelProject Based Learning strategi yang digunakan adalah penerapan melalui proyek sebagai sarana untuk pembelajaran supaya mencapai kompetensi sikap, pengetahuan, dan keterampilan.

Berdasarkan uraian tersebut bahwa Problem Based Learning dapat diterapkan dalam pembelajaran matematika dan pembelajaran yang berpusat terhadap siswa, karena dapat membuat siswa ikut serta dalam proses kegiatan penyelesaian masalah. Sedangkan pada Project Based Learning siswa dapat belajar secara mandiri dan terlibat langsung yang berperan aktif dalam penyelesaian masalah. Model berbasis proyek ini juga merupakan model 


\section{Jurnal Riset Pendidikan Dasar, 03 (1), April 2020 (51-56)}

RetnoTriningsih, Mawardi

pembelajaran yang menuntut siswa untuk menghasilkan suatu produk yang relistik.

Pada penelitian sebelumnya yang pernah dilakukan olehRahayudanHartono (2016: 1)menunjukan bahwa model PBL setting GI dan $\mathrm{PjBL}$ setting GI tidak terdapat perbandingan kedua model ditinjau dari prestasi belajar, kemampuan berpikir kritis, dan motivasi belajar matematika. Chanifah, Relmasira, \& Hardini (2019: 167) Berdasarkan hasil penelitian yang telah dilaksanakan di SD Negeri Ledok 05 Salatiga dengan menerapkan model pembelajaran Problem Based Learning, dapat disimpulkan bahwa model Problem Based Learning dapat meningkatkan kemampuan berpikirkritis dan hasil belajar siswa kelas V SD Negeri Ledok 05 Salatiga.

Ramadiyanti, Muderawan, \&Tika (2016: 204) melaksanakan penelitian mengenai pengaruh model pembelajaran berbasis proyek terhadap keterampilan berpikir kritis dan prestasi belajar siswa. Hasil dari penelitian tersebut adalah yang pertama, terdapat perbedaan keterampilan berpikir kritis dan prestasi belajar antara kelompok siswa yang belajar dengan model pembelajaran berbasis proyek dan model pembelajaran langsung $(\mathrm{F}=$ $59,161 ; \mathrm{p}<0,05)$. Kedua, terdapat perbedaan signifikan variabel model pembelajaran terhadap keterampilan berpikirkritis $(\mathrm{F}=$ $15,100 ; \mathrm{p}<0,05)$. Ketiga terdapat perbedaan signifikan variabel model pembelajaran terhadap prestasi belajar siswa $(F=67,849$; $\mathrm{p}<0,05)$.

Yovita, Mawardi, Astuti (2018: 139) menyatakan bahwa model Problem Based Learning baik digunakan untuk pembelajaran Matematika yang memiliki rata-rata lebih tinggi dibandingkan dengan model Discovery Learning.

Hayati, Utaya, dan Astina (2016: 7) melaksanakan penelitian dengan hasilStudent Worksheet Berbasis Project Based Learning dalam mengembangkan kemampuan berpikir kritis siswa setelah proses belajar sebesar 58\% mempunyai kualifikasi berpikir kritis baik. Kedua, perlakuan timbal balik yang dilakukan peserta didik terhadap Student Worksheet berbasis
Project Based Learning sebesar 78,68\% memiliki kualifikasi layak, yang berarti produk yang didapatkan diterima peserta didik dan proses belajar mengajar dapat dilaksanakan dengan baik. Berdasarkan penelitian yang telah dilakukan sebelumnya mengenai efektivitas model pembelajaran Problem Based Learning dan model pembelajaran Project Based Learning menimbulkan keragu-raguan kepada penulis mengenai model pembelajaran yang lebih baik dalam upaya peningkatan proses belajar siswa kelas 5 SD.

Berhubungan dengan hal tersebut, maka tujuan peneliti adalah untuk mendeskripsikan efektivitas Problem Based Learning dan Project Based Learning ditinjau dari keterampilan berpikir kritis siswa SD serta untuk mengetahui model manakah yang lebih efektif untuk digunakan dalam proses pembelajaran yang menjadi titik fokus pada penelitian ini.

Berdasarkan uraian di atas maka peneliti terfokus terhadap model pelajaran Problem Based Learning dan Project Based Learning yang ditinjau dari keterampilan berpikir kritis siswa kelas 5 SD. Maka dari itu peneliti ingin menerapkan penelitian yang berjudul "efektivitas Problem Based Learning dan Project Based Learning ditinjau dari keterampilan berpikir kritis SD". Pada penelitian ini penulis akan membandingkan dua model pembelajaran yaitu model pelajaran Problem Based Learning dan Project Based Learning pada materi pengumpulan dan penyajian data. Pada hasil penelitian ini dapat menjadi acuan pertimbangan untuk memilih model yang baik maupun yang cocok untuk diterapkan maupun digunakan pada saat proses belajar mengajar, khususnya untuk pembelajaran matematika pada materi pengumpulan dan penyajian data.

\section{METODE}

Jenis penelitian yang digunakan pada penelitian ini adalah quasi eksperimen dengan menggunakan desain Posttest-Only Control Group Design. Pada penelitian ini peneliti membandingkan dua kelompok, yaitu 
kelompok eksperimen 1 dan kelompok eksperimen 2 yang dapat digambarkan:

$\begin{array}{lll}01 & X 1 & 0 \\ 03 & X 2 & 0\end{array}$

Gambar 1.Posttest-Only Control Group Design

Keterangan:

R: Kelompok Rambang

$\mathrm{X}$ : Treatment yang diberikan

O: Nilai tes akhir

Sampel penelitian ini adalah peserta didik kelas 5 SD di Gugus Diponegoro, yaitu SDN Mangunsari 01, SDN Mangunsari 03, dan SDN Mangunsari 05 yang terletak di Kecamatan Sidomukti, Salatiga, Jawa Tengah dengan jumlah keseluruhan terdapat 111 siswa. Dalam penelitian ini peneliti membagi 2 kelompok dalam 1 kelas sebagaimana kelompok 1 merupakan eksperimen 1 dengan jumlah 56 siswa yang diberikan perlakuan pembelajaran menggunakan modelProblem Based Learning, sedangkan pada kelompok 2 merupakan eksperimen 2 dengan jumlah 55 siswa yang diberikan perlakuan pembelajaran menggunakan modelProject Based Learning.

Untuk mendapatkan data pada penelitian ini dibutuhkan teknik pengumpulan data. Teknik pengumpulan data teknistes. Teknik tes yang diberikan berupa soal evaluasi yang harus diselesaikan oleh siswa supaya dapat terlihat sebagai tujuan dari pembelajaran dan dapat diperbandingkan dengan nilai yang dicapai pada teste lainnya. Instrument tes yang dipakai pada penelitian ini yaitu instrument tes keterampilan berpikir kritis. Penelitian ini menggunakan soal evaluasi uraian yang berjumlah 5 soal pertanyaan dengan memilih mata pelajaran matematika kelas 5 dengan materi ajar pengumpulan dan penyajian data. Teknik analisis data memakai teknik statistik deskriptif. Teknik statistik dilakukan jika memenuhi uji prasyarat, yaitu uji normalitas, dan uji homogenitas,.

\section{HASIL DAN PEMBAHASAN}

Berhubungan dari penelitian yang telah dilakukan terhadap peserta didik kelas 5 SDN Mangunsari 01, SDN Mangunsari 03, SDN Mangunsari 05 pada tahun pelajaran 2019/2020. Pembagian kelas dibagi secara random dengan membagi 2 kelompok dalam satu kelas, dimana perlakuan pembelajaran berbeda, yaitu kelas eksperimen satu memakai modelProblem Based Learning dan kelas eksperimen duamemakai modelProject Based Learning.

Analisis deskriptif berguna untuk mengetahui sejauh mana efektifitas Problem Based Learning dan Project Based Learning ditinjau dari keterampilan berpikir kritis siswa SD. Pengolahan data memakai program SPSS 22.0, untuk melihat efektivitas model Problem Based Learning dan Project Based Learning. Dari perhitungan analisis deskriptif maka diperoleh hasil pada tabel 1 .

Tabel 1. Skor keterampilan berpikir kritis

\begin{tabular}{ccc}
\hline Skor & \multicolumn{2}{c}{ Eksperimen } \\
\cline { 2 - 3 } & PBL & PjBL \\
Jumlah Siswa & 56 & 55 \\
Nilai & 68 & 28 \\
Minimum & & \\
$\quad$ Nilai & 100 & 100 \\
Maksimim & 92.46 & 85.16 \\
Mean & 8.969 & 16.160 \\
$\quad$ Std. & & \\
Deviation &
\end{tabular}

Dari tabel tersebut maka pada kelas eksperimen satu yang menggunakan model Problem Based Learning dengan jumlah siswa 56 dengan nilai minimum 68; nilai maksimum 100; mean 92.46; dan standart deviation 8.969. sedangkan kelas eksperimen dua yang menggunakan model Project Based Learningdengan jumlah siswa 55 dengan nilai minium 28; nilai maksimum 100; mean 85.16; dan standart deviation 16.160. Jadi, dari hasil penelitian tersebut dapat terlihat bahwa model Problem Based Learning dan Project Based Learning mempunyai perbedaan. 
Tabel 2. Hasil Uji T

Descriptives

\begin{tabular}{|c|c|c|c|c|c|c|c|c|c|}
\hline \multicolumn{2}{|c|}{$\begin{array}{l}\text { Levene's Test for } \\
\text { Equality of } \\
\text { Variances }\end{array}$} & \multicolumn{7}{|c|}{ t-test for Equality of Means } & \\
\hline \multirow[t]{2}{*}{$\mathrm{F}$} & \multirow[t]{2}{*}{ Sig. } & \multirow[t]{2}{*}{$\mathrm{T}$} & \multirow[t]{2}{*}{$\mathrm{df}$} & \multirow{2}{*}{$\begin{array}{l}\text { Sig. } \\
(2- \\
\text { tailed } \\
\quad)\end{array}$} & \multirow[t]{2}{*}{$\begin{array}{l}\text { Mean } \\
\text { Differ } \\
\text { ence }\end{array}$} & \multirow{2}{*}{$\begin{array}{c}\text { Std. } \\
\text { Error } \\
\text { Differe } \\
\text { nce }\end{array}$} & \multicolumn{2}{|c|}{$\begin{array}{l}95 \% \text { Confidence } \\
\text { Interval of the } \\
\text { Difference }\end{array}$} & \\
\hline & & & & & & & Lower & Upper & \\
\hline $\begin{array}{l}\text { Berpikir- } \\
\text { kritis }\end{array}$ & 5.253 & .024 & 2.007 & 109 & .047 & 5.066 & 2.524 & .063 & $\begin{array}{r}10.0 \\
68\end{array}$ \\
\hline
\end{tabular}

Tabel di atas memiliki nilai Sig. (2-tailed) sebesar 0,047<0,05 dengan demikian terdapat perbedaan bermakna antara kedua kelompok yang berarti $\mathrm{H} 1$ diterima dan Ha ditolak. Dari hasil evaluasi soal diketahui bahwa yang diberi tindakan menggunakan model Problem Based Learning lebih tinggi daripada model Project Based Learning.

Konsep lain dari uraian tersebut, yaitu siswa peroleh dari kegiatan penyelidikan dan proyek, diterapkan untuk menyelesaikan masalah sehingga siswa mendapatkan pengalaman yang bermakna dalam mendapatkan pengetahuan. Melalui kegiatan proyek dan penyelesaian masalah, siswa dilatih untuk menggunakan kemampuan berpikir kritisnya, yaitu menggunakan keterampilan menginterpretasi, menganalisis, mengevaluasi, dan membuat kesimpulan serta mampu menjelaskan argumen. Pada penelitian ini terlihat bahwa perlakuan yang menggunakan model Problem Based Learningterdapat tingkat keterampilan berpikir kritis lebih tinggi daripada Project Based Learning.

Hasil penelitian ini sama halnya dengan penelitian yang sudah dilakukan oleh Harahap dan Prastowo (2010) menunjukkan bahwa model Project Based Learning dan Problem Based Learningmempunyai signifikansi rata-rata hasil belajar yang berbeda lebih efektif menggunakan modelProject Based Learning. Pada penelitian Pramesti (2012) dengan menunjukkan model Problem Based Learning lebih efektif dalam meningkatkan hasil belajar.Rista, Stefanus, Agustina (2019) menunjukkan model Problem
Based Learning lebih efektif untuk menumbuh kembangkan hasil belajar Matematika dibandingkan dengan model Project Based Learning.Begitu juga dengan penelitian yang dilakukan dengan Yovita, Mawardi, Astuti (2018: 139) menyatakan bahwa model pembelajaran Problem Based Learning baik digunakan untuk pembelajaran matematika yang memiliki rata-rata lebih tinggi daripadamenggunakan model Discovery Learning.

Walaupun terdapat perbedaan keefektivan antara model Problem Based Learning dan Project Based Learning, keduanya efektif dalam pembelajaran matematika khususnya untuk materi pengumpulan dan penyajian data. Efektif yang dimaksudkan adalah efektif ditinjau dari keterampilan berpikir kritis matematika. Dengan demikian baik model Problem Based Learning dan model Project Based Learning sebagai model pembelajaran yang dapat meningkatkan prestasi belajar, akan tetapi lebih efektif model Problem Based Learning dari pada Project Based Learning yang ditinjau dari keterampilan berpikir kritiis.

\section{SIMPULAN}

Berdasarkan penelitian yang telah dilaksanakan tentang efektivitas Problem Based Learning dan Project Based Learningditinjau dari keterampilan berpikir kritis peserta didik SD dapat disimpulkan bahwa keterampilan berpikir kritis peserta didik SDyang dilakukanproses belajar mengajar menggunakan model Problem 
Based Learning lebih tinggi darimodelProject Based Learning.

\section{DAFTAR PUSTAKA}

Chanifah, M., Relmasira, S. C., \&Hardini, A. T. A. (2019).Upaya Meningkatkan Kemampuan Berpikir Kritis dan Hasil Belajar pada Pembelajaran Matematika Menggunakan Model Pembelajaran Problem Based Learning pada SiswaKelas V SD. Jurnal Basicedu, 3(1), 163-168.

Rahayu, E., \& Hartono, H. (2016). Keefektifan model PBL dan PjBL ditinjau dari Prestasi, Kemampuan Berpikir Kritis, dan Motivasi Belajar Matematika Siswa SMP. PYTHAGORAS:Jurnal Pendidikan Matematika, 11(1), 1-10.

Fiana, Rista Okta, Stefanus Christian Relmasira, \& Agustina Tyas Asri Hardini. (2019). Perbedaan Penerapan Model Project Based Learning Dan Problem Based Learning Terhadap Hasil Belajar Matematika Kelas 4 Sd. Jurnal Basicedu 3 (1):157-62. https://doi.org/10.31004/basicedu.v3i1.1 08.

Hayati, Wahyu, Sugeng Utaya, \& I Astina. (2016). Efektivitas Student Worksheet Berbasis Project Based Learning Dalam Menumbuhkan Kemampuan Berpikir Kritis Siswa Pada Mata Pelajaran Geografi. Jurnal Pendidikan - Teori, Penelitian, Dan Pengembangan 1 (3): 46874. https://doi.org/10.17977/jp.v1i3.6174.

L.R.Gay, Geoffrey E. Mills, \& Peter Airasian. (2011). "Cloaking Malware with the Trusted Platform Module." Proceedings of the 20th USENIX Security Symposium.

Oktaviani, B. A. Y., Mawardi, M., \& Astuti, S. (2018). Perbedaan Model Problem Based Learning dan Discovery Learning Ditinjau Dari Hasil Belajar Matematika Siswa Kelas 4 SD. Scholaria: Jurnal Pendidikan dan Kebudayaan, 8(2), 132-141.

Ramadiyanti, N., Muderawan, I. W., \& Tika, I. N. (2016), August).Pengaruh Model Pembelajaran Berbasis Proyek Terhadap Keterampilan Berpikir Kritis dan Prestasi Belajar Siswa.In Prosiding Seminar Nasional MIPA. 